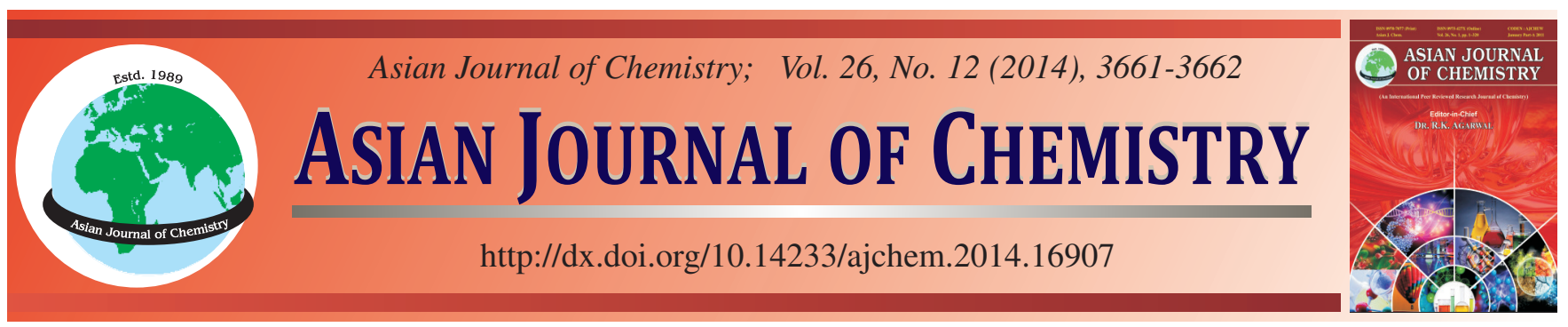

NOTE

\title{
Hydrothermal Synthesis and Crystal Structure of Cadmium(II) 4-(2-Pyridin-4-yl-vinyl)benzoate
}

\begin{abstract}
Y. ZHAO ${ }^{1, *}$ and L. ZHANG ${ }^{2}$
${ }^{1}$ College of Physics and Electronic Information, Luoyang Normal University, Henan, P.R. China

${ }^{2}$ College of Chemistry and Chemical Engineering, Luoyang Normal University, Henan, P.R. China

*Corresponding author: Tel/Fax: +86 379 65515016; E-mail: luoyangchangchun@126.com

Received: 23 December 2013;

Accepted: 15 April 2014;

Published online: 5 June 2014;

AJC-15315

One new cadmium complex with the formula $\mathrm{Cd}\left(\mathrm{C}_{14} \mathrm{H}_{10} \mathrm{NO}_{2}\right)$ is formed by reacting $\mathrm{Cd}(\mathrm{OAc})_{2} .4 \mathrm{H}_{2} \mathrm{O}$ and 4-(2-pyridin-4-yl-vinyl)-benzoic acid under hydrothermal conditions. The compound has been characterized by X-ray single-crystal diffraction, Compound shows a onedimensional framework. The 1D supramolecular structure is formed via hydrogen bonding connection.

Keywords: Coordination polymer, Crystal structure, Cadmium(II).
\end{abstract}

Metal organic frameworks (MOFs) have received much attention in the field of crystal engineering and supramolecular chemistry because of their diverse structures and promising applications in functional materials such as luminescent materials, gas adsorption and magnetism ${ }^{1-4}$. Hydrogen bonds are well suited for the design of polymeric arrangement and crystal engineering because of their important directional interactions and because they can interlink 1-D, or 3-D structures into higherdimensionality system ${ }^{5,6}$

All reagent and solvents employed were commercially available and used as received without further purification.

General procedure: A mixture of $\mathrm{Cd}(\mathrm{OAc})_{2} .4 \mathrm{H}_{2} \mathrm{O}(0.25$ $\mathrm{mmol})$, 4-(2-Pyridin-4-yl-vinyl)-benzoic acid (0.25 mmol), $\mathrm{KOH}(0.05 \mathrm{mmol})$ and distilled water $(8 \mathrm{~mL})$ was heated in a $25 \mathrm{~mL}$ stainless steel reactor with a Teflon liner $403 \mathrm{~K}$ for $36 \mathrm{~h}$, followed by slow cooling to room temperature. Yellow crystals were obtained (Fig. 1).

Detection method: Single-crystal diffraction data of the title complex with the dimensions of $0.39 \times 0.17 \times 0.15 \mathrm{~mm}$ were collected on a Bruker SMART APEXII CCD diffractometer equipped with a graphite monochromated $\mathrm{MoK}_{\alpha}$ radiation $(\lambda=0.71073 \AA$ ) by using a $\omega$-scan mode. All the structures were solved by direct methods and refined by fullmatrix least-squares methods on $\mathrm{F}^{2}$ using the program SHEXL $97^{7}$. All non-hydrogen atoms were refined anisotropically. The hydrogen atoms were located by geometrically calculations and their positions and thermal parameters were fixed during the structure refinement. The crystallographic data and experimental details of structural analyses for coordination polymers are summarized in Table- 1 . Selected bond and angle parameters are listed in Table-2.

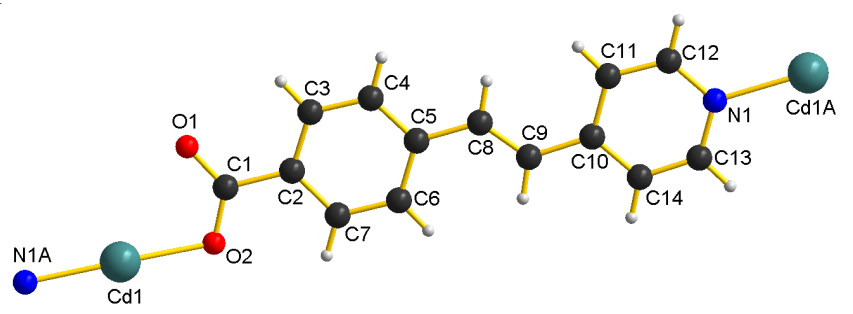

Fig. 1. Molecular structure of the title compound at $30 \%$ probability displacement ellipsoids

$\mathrm{X}$-ray diffraction analysis revealed that the fundamental building unit consists of $\mathrm{Cd}(\mathrm{II})$ ion and 4-(2-pyridin-4-ylvinyl)-benzoic acid as bridging ligands to construct a new coordination polymer. On the benzene ring, the hydrogen atoms were assigned with $\mathrm{Uiso}(\mathrm{H})=1.2 \mathrm{Ueq}(\mathrm{C})$ and included in the final refinement by using geometrical restraints, with $\mathrm{d}(\mathrm{C}---\mathrm{H})=0.931 \% \mathrm{~A}$. In the carboxylic and the carboxylate group $^{8}$, bond length of C1-C2 is $1.502(10) \AA$, The molecule is almost planar, but the dihedral angle between benzene ring and pyridine ring is $3.29^{\circ}$. The bond $\mathrm{C}(8)-\mathrm{C}(9)$ is a double bond and this is confirmed by the bond length of 1.312(11) $\AA$. The bond length of $\mathrm{Cd}(1)-\mathrm{N}(1) \# 1, \mathrm{Cd}(1)-\mathrm{O}(2)$ are found to be only $2.133(6), 2.122(5) \AA$, respectively. Symmetry codes: 
TABLE-1

CRYSTALLOGRAPHIC DATA AND STRUCTURE REFINEMENT SUMMARY OF Cd( $\left.\mathrm{C}_{14} \mathrm{H}_{10} \mathrm{NO}_{2}\right)$

\begin{tabular}{llll}
\hline Empirical formula & $\mathrm{C}_{14} \mathrm{H}_{10} \mathrm{NO}_{2} \mathrm{Cd}$ & $\mathrm{Z}$, Calculated density $\left(\mathrm{mg} / \mathrm{m}^{3}\right)$ & $4,1.964$ \\
Formula weight & 336.63 & Absorption coefficient $\left(\mathrm{mm}^{-1}\right)$ & 1.908 \\
Crystal system space group & Monoclinic, $\mathrm{P} 2(1) / \mathrm{n}$ & $\mathrm{F}(000)$ & 660 \\
Unit cell dimensions & $\mathrm{a}=4.735(2) \AA$ & Limiting indices & $-5 \leq \mathrm{h} \leq 5$ \\
& $\mathrm{~b}=8.594(4) \AA$ & & $-10 \leq \mathrm{k} \leq 9$ \\
& $\mathrm{c}=27.981(14) \AA$ & $-33 \leq 1 \leq 32$ \\
Volume $\left(\AA^{3}\right)$ & $1138.6(10)$ & Largest diff. peak and hole $\left(\mathrm{e} / \AA^{3}\right)$ & 0.998 and-0.629 \\
$\theta$ range for data collection & $2.48-25.50$ & Goodness-of-fit on $\mathrm{F}^{2}$ & 1.079 \\
Final $\mathrm{R}$ indices $[\mathrm{I}>2 \sigma(\mathrm{I})]$ & $\mathrm{R}_{1}=0.0576 \mathrm{wR}_{2}=0.1207$ & $\mathrm{R}$ indices (all data) & $\mathrm{R}_{1}=0.1072, \mathrm{wR}_{2}=0.1390$ \\
\hline
\end{tabular}

TABLE-2

SELECTED BOND LENGTHS $(\AA)$ AND ANGLES $\left({ }^{\circ}\right)$ FOR Cd $\left(\mathrm{C}_{14} \mathrm{H}_{10} \mathrm{NO}_{2}\right)$

\begin{tabular}{cccc}
\hline $\mathrm{Cd}(1)-\mathrm{O}(2)$ & $\mathrm{N}(1)-\mathrm{C}(12)$ & $1.346(11)$ \\
$\mathrm{Cd}(1)-\mathrm{N}(1) \# 1$ & $2.133(6)$ & $\mathrm{O}(1)-\mathrm{C}(1)$ & $1.236(10)$ \\
$\mathrm{N}(1)-\mathrm{C}(13)$ & $1.330(11)$ & $\mathrm{O}(2)-\mathrm{C}(1)$ & $1.269(10)$ \\
$\mathrm{O}(2)-\mathrm{Cd}(1)-\mathrm{N}(1) \# 1$ & $173.4(3)$ & $\mathrm{C}(1)-\mathrm{O}(2)-\mathrm{Cd}(1)$ & $110.4(5)$ \\
$\mathrm{C}(13)-\mathrm{N}(1)-\mathrm{Cd}(1) \# 2$ & $\mathrm{O}(1)-\mathrm{C}(1)-\mathrm{O}(2)$ & $125.3(7)$ \\
$\mathrm{C}(13)-\mathrm{N}(1)-\mathrm{C}(12)$ & $\mathrm{O}(1)-\mathrm{C}(1)-\mathrm{C}(2)$ & $118.7(8)$ \\
$\mathrm{C}(12)-\mathrm{N}(1)-\mathrm{Cd}(1) \# 2$ & $\mathrm{O}(2)-\mathrm{C}(1)-\mathrm{C}(2)$ & $116.0(8)$ \\
\hline Symmetry codes: (i) $\mathrm{x}-3 / 2,-\mathrm{y}+1 / 2, \mathrm{z}-1 / 2$ (ii) $\mathrm{x}+3 / 2,-\mathrm{y}+1 / 2, \mathrm{z}+1 / 2$ & &
\end{tabular}

$\# 1 \mathrm{x}-3 / 2,-\mathrm{y}+1 / 2, \mathrm{z}-1 / 2$. The chains are further assembled by the intermolecular hydrogen bonding interaction leading to the formation of a 1D framework (Fig. 2).

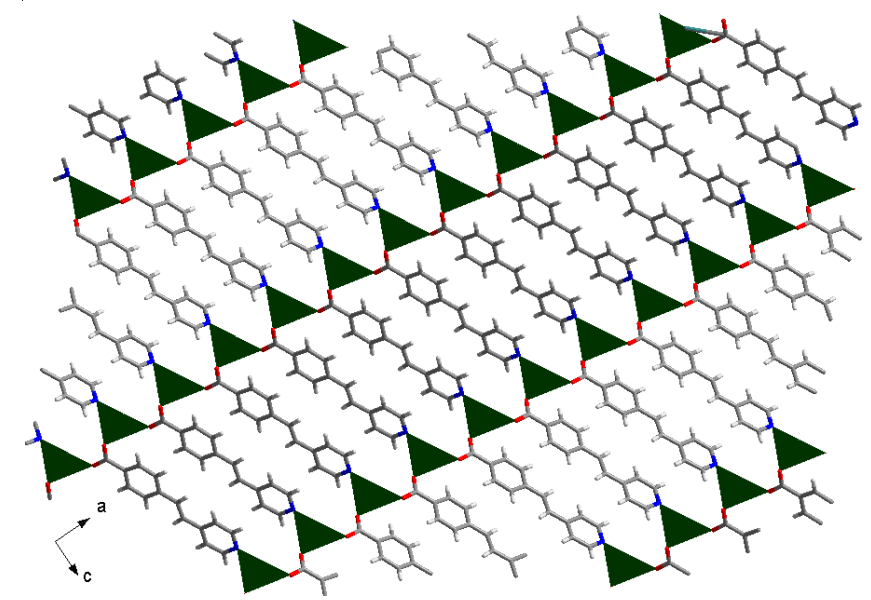

Fig. 2. 1D structure formed via hydrogen bonding interactions

\section{REFERENCES}

1. B.O. Patrick, C.L. Stevens, A. Storr and R.C. Thompson, Polyhedron, 24, 2242 (2005).

2. Y.H. Wen, J.K. Cheng, Y.L. Feng, J. Zhang, Z.L. Li and Y.G. Yao, Inorg. Chim. Acta, 358, 3347 (2005)

3. X.L. Wang, C. Qin, E.B. Wang and L. Xu, J. Mol. Struct., 749, 45 (2005).

4. S.R. Batten and K.S. Murray, Coord. Chem. Rev., 246, 103 (2003).

5. T.L. Hu, R.Q. Zou, J.R. Li and X.H. Bu, J. Chem. Soc., Dalton Trans., 1302 (2008).

6. J.F. Song, Y. Chen, Z.G. Li, R.S. Zhou, X.Y. Xu and J.Q. Xu, J. Mol. Struct., 842, 125 (2007).

7. G.M. Sheldrick, SHELXTL97, Program for the Refinement of Crystal Structure, University of Gottingen, Germany (1997).

8. X.-M. Zhang, Y.-Z. Zheng, C.-R. Li, W.-X. Zhang and X.-M. Chen, Cryst. Growth Des., 7, 980 (2007). 